\title{
The asymmetric nexus of entrepreneurship and environmental quality in a developing economy
}

\author{
L. D. Philip ${ }^{1}$ F. Emir ${ }^{1}$ A. A. Alola ${ }^{2,3}$
}

Received: 27 April 2021 / Revised: 1 August 2021 / Accepted: 11 September 2021 / Published online: 5 October 2021

(c) The Author(s) 2021

\begin{abstract}
In spite of the vital role entrepreneurship plays in an economy, recent observations especially from the perspective of climaterelated economic activities are indications for the inclusive probe of other salient elements responsible for environmental challenges. Considering the aforementioned framework, therefore, this study explores the asymmetric impact of entrepreneurship on the environmental quality for a developing economy such as Turkey. In a unique dimension, this study utilizes the nonlinear autoregressive distributed lag model with the aid of yearly data from 1985-2016 while incorporating other related determinants of environmental sustainability. The estimation results depict the presence of asymmetric short-run and long-run impact of the explanatory variables on environmental quality. Interestingly, the results confirm a negative impact of entrepreneurial activities, energy utilization, financial development, and economic growth on the environmental quality irrespective of the nature (either positive or negative) of the shock in the short and long run. However, a positive (negative) shock in trade openness worsens (improve) environmental quality in the short and long run. Furthermore, the investigation affirms the existence of the environmental Kuznets curve (EKC) for Turkey. The main outcome from this paper shows that entrepreneurship has a crucial effect on the environment of Turkey. Generally, this study suggests the introduction of incentives to motivate the creation of sustainable businesses, technological innovation, and smart cities to mitigate its negative impact on the environment is far begging for critical attention in the country.
\end{abstract}

Keywords Developing economy $\cdot$ Environmental sustainability $\cdot$ Nonlinear autoregressive distributed lag $\cdot$ Turkey

\section{Introduction}

Entrepreneurship shows a vital source of the development of a country and the stimulation of income generation as well as promotes social responsibilities. To buttress this fact, the current Global Entrepreneurial Report ranked Turkey as the second most entrepreneurial country in the world after India

Editorial responsibility: Q. Aguilar-Virgen.

A. A. Alola

aadewale@gelisim.edu.tr

1 Department of Economics, Faculty of Business and Economics, Eastern Mediterranean University, via Mersin 10, Famagusta, Turkey

2 Department of Economics and Finance, Faculty of Economics Administrative and Social Sciences, Istanbul Gelisim University, Istanbul, Turkey

3 Department of Economics, School of Accounting and Finance, University if Vaasa, Vaasa, Finland which came first due to its ability of achieving great feasibility, self-funding willingness and experience as well as high early stage business activity (Global Entrepreneurial Report 2020). The report further illustrates that the USA is ranked third after Turkey by virtue of its capacity of supporting new businesses as well as small- and medium-scale enterprises with financial resources. According to the Global Entrepreneurial Monitor (GEM), entrepreneurship has the propensity to enable different countries to reduce poverty and overcome their current economic challenges by reallocating resources from old economic activities to more productive and more effective ones by the high number of skilled entrepreneurs in a country (GEM 2008). Similarly, activities closely linked to entrepreneurship can spur employment opportunities and re-invigorate an era of innovation which are essential for industrial and economic growth. Schumpeter, a renowned economist and the first scholars to create theories on entrepreneurship, stated that entrepreneurial activities are the main tool for economic growth (Schumpeter 1947). New entrepreneurs offer efficient resources with regard to 
recognizing current opportunities, technology, and the concept of marketing, to achieve economic growth.

Research has shown that certain increase in entrepreneurship and innovation improves economic growth, and then later, economic growth increases entrepreneurship. The association among entrepreneurship, innovation, and economic performance is one that requires a careful dissection to understand its effects and associated consequences to a given economy. Urbano and Aparicio (2016) stated that total entrepreneurship activities (TEA) have positive and greater influence on economic performance, similarly Gerceker and Ozel (2014) for Turkey.

Indeed, the effective use of entrepreneurial landscape can increase revenue for an economy and reduce welfare costs and inequality. Turkish, for instance, attracts high caliber entrepreneurship, and its growth depends on its successful entrepreneurs and environmental quality. Turkey is located between key economies in Europe, Central Asia, Middle East, and Russia. Environmental pollution and climate change have been reflected as the greatest challenges to an economy. Environmental pollution has negatively affected economic sustainability for a long time, and attention has been giving to it all over the world to reduce its effect on future economic sustainability. Turkey has been faced with environmental challenges being a top industrial economy with rapid urbanization and population growth, which consequently affect its growth and development. The challenges can manifest in various forms such as climate change, deforestation, and water-related issues (European Environmental Agency 2015). A great number of studies consider entrepreneurship as one of the major elements responsible for these environmental pollutions. Cohen and Winn (2007) and Riti et al (2015) indicated in their various research that entrepreneurship contributes to environmental degradation. Nevertheless, others believed entrepreneurship reduces pollution: York and Venkataraman (2010) and Shepherd and Patzett (2011).

Financial institutions are relevant for economic growth especially in developing economies by providing sufficient capital for businesses and productivity, by acquiring advanced technology and managerial skills. Financial institutions also create alternative jobs and encourage innovations and competitiveness which are highly important for sustainable economic growth. Notwithstanding the significance of financial development in promoting economic growth, it also has disadvantages. With the contribution of financial institutions to Turkish economy, it will be instructive to test the impact of the growth in financial development on the environmental sustainability of Turkey. Many studies have confirmed the positive and negative impact of financial development on environmental quality ( $\mathrm{Lv}$ and $\mathrm{Li}$ 2021; Abbasi and Riaz 2016).

Thus, the main purpose of this paper is to analyze the asymmetric short-run and long-run association among entrepreneurship and environmental quality by incorporating the economic performance, trade openness, financial development and nonrenewable energy use for the period of 1985-2016 in Turkey. Although several researches have outlined the consequence of entrepreneurship on Turkish economy, researchers have yet to analyze the asymmetric association between entrepreneurship and the quality of environment in Turkey. On this note, the present study uniquely explores this relationship by using the nonlinear autoregressive distributed lag (NARDL) model by testing the asymmetric relations among the variables. This perspective is germane in the literature of environmental sustainability, and especially in the case of a developing economy such as Turkey. Thus, the contribution to the existing literature is from the standpoint of both empirically and theoretically approaches. This is achieved by examining the association of entrepreneurship and environmental quality (with carbon dioxide, $\mathrm{CO}_{2}$ as a proxy) by incorporating the financial development, economic performance, nonrenewable energy, and openness. Specifically, to the best of our knowledge, none of the prior research has considered the short-run and long run asymmetric nexus between entrepreneurship and environmental quality in Turkey by employing NARDL approach.

The remaining parts of this work are constructed as follows. The following part makes a comprehensive review of the previous studies. The third part offers the data and methods. Part four introduces the estimation results, and economic implications. The last part of the paper concludes our study with policy implications.

\section{Literature review}

Several researchers had analyzed the influence of entrepreneurship on economic growth but very few on how it impacts the environment. For instance, York and Venkataraman (2010), Shepherd and Patzett (2011), and Omri and Afi (2020) applied different approaches to examine the linkage between entrepreneurship and environmental sustainability. Specifically, York and Venkataraman (2010) employed the entrepreneurship theory to present a model that illustrates the relevance of entrepreneurial action in addressing the fundamental factors confronting environmental quality. While noting the direct bearing environmental effects of uncertainty, innovation, and resource allocation, York and Venkataraman (2010) opined that the outlined model adopts entrepreneur action to solve these problems arising from environmental uncertainty, triggers innovation, and resource allocation. Similarly, Omri and Afi (2020) implemented the system Generalized Method of Moments (Sys-GMM) to investigate the impact of entrepreneurship and educational capital (government spending on education) on the environmental quality of selected 32 developing economies over the period 
2001-2015. The study found that entrepreneurship contributes to economic growth and, on the centrally, impact the environment negatively by contributing to the increase in environmental degradation. At the same time, the study found that government spending on education reduces environmental degradation in the examined panel countries. Additionally, Nakamura and Managi (2020) designated that the influence of entrepreneurship on the environment varies across the economies. The study revealed that in high-income economies, the effects of entrepreneurial activities on ecological pollution are low compared to low-income economies which causes more pollution. Thus, the study revealed a U-shaped association between marginal cost of $\mathrm{CO}_{2}$ and entrepreneurship in the stages of economic development. However, in the study of Cohen and Winn (2007), the investigation motioned that entrepreneurship promotes environmental pollution. As such, the study concluded that sustainable entrepreneurship has the possibility to reduce emissions and enhance environmental quality by providing the opportunity for innovative technologies in different sectors.

Over the past decades, several studies have illustrated the relationship among the economic performance or indicators and environmental quality for many cases, countries and regions with different analyses. Some of the studies offered that increase in gross domestic product (GDP) deteriorates the environment (Balsalabre-Lorente et al. 2018; Saint Akadiri et al. 2020). On the other hand, many studies have also reported the desirability of economic growth in mitigating carbon emission (Alola et al. 2021; Umar et al. 2021). For instance, Balsalabre-Lorente et al. (2018) implemented the case of the European Union 5 (EU-5) countries (France, Germany, Italy, Spain, and the UK) over the period 1985-2016 to reveal that an increase in GDP dampens environmental quality. Specifically, the study revealed that the relationship between economic growth and environmental degradation is an N-shaped pattern. In another study, Alola et al (2019) examined the importance of attaining sustainability with respect to decreasing the level of deterioration in the environment of the EU members using the ARDL model from the period 1997 to 2014. Importantly, the study found that a rise in real GDP escalates the quality of the environment. While this perspective has been illustrated in the literature, Cai et al. (2018) found more interesting result when the ARDL was employed to test the association among energy, environment quality, and economy for G7 countries. Specifically, the study discovered that there is no evidence of cointegration among the examined variables in the US, UK, Canada, Italy, and France except in Germany and Japan.

Moreover, Cowan et al. (2014) implemented the bootstrap panel causality approach that is capable of accounting for cross section dependency and heterogeneity dynamics for the case of the Brazil, Russia, India, China, and South Africa (the BRICS economies) over the period 1990-2010. Specifically, the study examined the causal link among electricity use, environmental deterioration, and economic growth for the in a panel Granger causality approach. Thus, Cowan et al. (2014) found non-existence of Granger causality between economic growth and environmental degradation in India and China. However, a feedback hypothesis of GDP and environmental degradation exists for Russia, and GDP causes $\mathrm{CO}_{2}$ emissions while for Brazil from $\mathrm{CO}_{2}$ emission to GDP. While considering the role of financial development and globalization, AhAtil et al (2019) used nonlinear autoregressive distributed lag methods to investigate symmetric and asymmetric effect of financial development, globalization, energy consumption, and economic growth on environmental degradation in China over the period 1970Q1-2015Q4. Importantly, the results showed the existence of the asymmetric effect of development in financial sector, economic growth, and globalization on carbon emission in the long run, while the short run revealed a symmetric effect from financial development and economic growth. Thus, the findings showed that economic growth, social globalization, and energy consumption positively impact carbon emission symmetrically, while the impact of financial development, political globalization, and overall globalization are without a significant effect. Nevertheless, Ibrahiem (2020) used a battery of empirical techniques that include auto-regressive distributed lag, fully modified ordinary least square, Stock and Watson dynamic ordinary least square, and the Toda-Yamamoto approaches to examine how alternative energy, technological innovation, economic expansion, and financial development affect Egypt's carbon mitigation drive during the period 1971-2014. While confirming an evidence of cointegration among the examined variables, the study discovered that financial development and economic expansion in Egypt escalate $\mathrm{CO}_{2}$ emissions. Meanwhile, the result revealed that technological innovation and alternative energy utilization are statistically significant drivers of sustainable environment in Egypt.

Evidently, many of the aforementioned literature as well as those shown in Table1 have attempted to extend the analysis of the entrepreneurship-growth-environmental degradation relationship in different perspectives. However, the current study seeks to further expand the literature by examining the symmetric and asymmetric perspective of entrepreneurship-environmental degradation nexus amidst other influences for a developing economy.

\section{Materials and methods}

Given the heterogeneity of the obtained results in the literature, this study pursues the nature of the nonlinear linkage between environmental quality $\left(\mathrm{CO}_{2}\right)$ and entrepreneurship (ENT) for the second most entrepreneurial country in the world, Turkey to contribute to the existing literature. This 
Table 1 Review of entrepreneurship, economic growth, energy consumption, financial development, and the environmental quality

\begin{tabular}{|c|c|c|c|c|}
\hline Authors & Year & Country & Variables & Results \\
\hline Philip et al. (2021) & $1970-2017$ & Turkey & $\begin{array}{l}\mathrm{GDP}, \mathrm{CO}_{2}, \mathrm{FDI}, \mathrm{ENC} \text {, and } \\
\text { URB }\end{array}$ & $\begin{array}{l}\text { The positive impact of real } \\
\text { GDP per capita on the envi- } \\
\text { ronment in Turkey }\end{array}$ \\
\hline Karasoy (2019) & $1965-2015$ & Turkey & $\begin{array}{l}\text { FD, RENC, } \mathrm{CO}_{2} \text { NRENC, } \\
\text { TO }\end{array}$ & $\begin{array}{l}\text { FD aggravate environmental } \\
\text { pollution } \\
\text { Positive shock of RENC and } \\
\text { NRENC increase } \mathrm{CO}_{2} \\
\text { TO increases emission }\end{array}$ \\
\hline Ozturk and Acarauci (2013) & 1960-2007 & Turkey & $\mathrm{FD}, \mathrm{CO}_{2}, \mathrm{GDP}, \mathrm{TO}, \mathrm{ENC}$ & $\begin{array}{l}\text { TO increases } \mathrm{CO}_{2} \\
\text { FD increases } \mathrm{CO}_{2}\end{array}$ \\
\hline Ahmed et al (2021) & $1971-2016$ & Japan & $\begin{array}{l}\text { EP, FD, GDP, ENC, GLB, } \\
\text { POP }\end{array}$ & FD increases footprint \\
\hline Ibrahiem (2020) & $1971-2014$ & Egypt & $\begin{array}{l}\mathrm{GDP}, \mathrm{FD}, \mathrm{CO}_{2} \text {, TI, and clean } \\
\text { energy sources }\end{array}$ & $\begin{array}{l}\text { FD reduces environmental } \\
\text { quality } \\
\text { TI and energy sources improve } \\
\text { environmental quality }\end{array}$ \\
\hline Omoke et al. (2020) & $1971-2014$ & Nigeria & $\begin{array}{l}\mathrm{GDP}, \mathrm{ENC}, \mathrm{FD}, \mathrm{CO}_{2}, \mathrm{URB} \text {, } \\
\text { and EXR }\end{array}$ & $\begin{array}{l}\text { Negative shock of FD } \\
\text { increases } \mathrm{CO}_{2} \text { emission, } \\
\text { while the positive shock of } \\
\text { FD reduces } \mathrm{CO}_{2} \text { emission }\end{array}$ \\
\hline Mikayiloy et al. (2018) & $1992-2013$ & Azerbaijan & GDP, $\mathrm{CO}_{2}$, and population & $\begin{array}{l}\text { Increase in GDP worsens envi- } \\
\text { ronmental deterioration }\end{array}$ \\
\hline Riti et al. (2015) & $2000-2012$ & Nigeria & $\begin{array}{l}\text { ENT, } \mathrm{CO}_{2} \text {, GDP, } \mathrm{HD} \text {, and } \\
\text { service sector }\end{array}$ & ENT increases $\mathrm{CO}_{2}$ \\
\hline Shahbaz et al (2013) & $1965-2008$ & South Africa & $\begin{array}{l}\mathrm{GDP}, \mathrm{CO}_{2}, \mathrm{FD}, \mathrm{TO} \text {, and coal } \\
\text { consumption }\end{array}$ & $\begin{array}{l}\text { Economic growth increases } \\
\mathrm{CO}_{2} \\
\text { TO contribute to environmen- } \\
\text { tal quality }\end{array}$ \\
\hline Saboori et al (2012) & 1980-2009 & Malaysia & $\mathrm{CO}_{2}, \mathrm{RGDP}$ & GDP increases $\mathrm{CO}_{2}$ \\
\hline Zhang (2011) & 1994-2009 & China & $\begin{array}{l}\mathrm{FD}, \mathrm{CO}_{2}, \mathrm{GDP}, \mathrm{FDI} \text {, stock } \\
\text { market }\end{array}$ & FD increases $\mathrm{CO}_{2}$ \\
\hline $\mathrm{Lv}$ and $\mathrm{Li}(2021)$ & 2000-2014 & 97 countries & $\begin{array}{l}\mathrm{FD}, \mathrm{CO}_{2}, \mathrm{GDP}, \mathrm{POP}, \mathrm{EU}, \\
\mathrm{URB} \text {, and TO }\end{array}$ & $\begin{array}{l}\text { FD increases environmental } \\
\text { quality }\end{array}$ \\
\hline Sharma et al (2020) & $1990-2015$ & $\begin{array}{l}8 \text { developing countries of } \\
\text { Southeast Asia }\end{array}$ & $\begin{array}{l}\text { GDP, REN,EP, POP, life } \\
\text { expectancy }\end{array}$ & $\begin{array}{l}\text { REN improves environmental } \\
\text { quality }\end{array}$ \\
\hline He et al (2020) & $2015-2017$ & 67 countries & $\mathrm{CO}_{2}, \mathrm{ENT}, \mathrm{GDP}, \mathrm{APS}, \mathrm{NES}$ & $\begin{array}{l}\text { Entrepreneurship has positive } \\
\text { effect on environmental } \\
\text { quality }\end{array}$ \\
\hline Bekun et al. (2019) & 1996-2014 & 16 EU-Countries & $\begin{array}{l}\text { RENC, NRENC,GDP, and } \\
\mathrm{CO}_{2} \text { emission }\end{array}$ & GDP increases $\mathrm{CO}_{2}$ emission \\
\hline $\begin{array}{l}\text { Balsalabre-Lorente et al. } \\
\text { (2018) }\end{array}$ & $1985-2016$ & 5 EU countries & $\begin{array}{l}\mathrm{GDP}, \mathrm{CO}_{2}, \mathrm{RENC}, \mathrm{TO}, \mathrm{EI}, \\
\text { and } \mathrm{NR}\end{array}$ & $\begin{array}{l}\text { Economic growth increases } \\
\mathrm{CO}_{2} \text { emission }\end{array}$ \\
\hline Dhahri and Omri (2018) & 2001-2012 & 20 developing countries & ENT, $\mathrm{CO}_{2}, \mathrm{GDP}, \mathrm{HD}$ & $\begin{array}{l}\text { ENT increases GDP } \\
\text { ENT negatively contributes to } \\
\text { the environmental conditions }\end{array}$ \\
\hline Omri (2018) & 2001-2011 & 69 countries & $\begin{array}{l}\text { ENT, } \mathrm{CO}_{2} \text { emission, GDP, } \\
\text { TO, ENC, FD, and human } \\
\text { development }\end{array}$ & $\begin{array}{l}\text { The effects of entrepreneurial } \\
\text { activities of high-income } \\
\text { economies on the environ- } \\
\text { mental pollution are low } \\
\text { compared to low-income } \\
\text { countries which causes more } \\
\text { pollution }\end{array}$ \\
\hline
\end{tabular}


Table 1 (continued)

\begin{tabular}{|c|c|c|c|c|}
\hline Authors & Year & Country & Variables & Results \\
\hline Youssef et al. (2018) & 2001-2014 & 17 African countries & $\begin{array}{l}\text { ENT, } \mathrm{CO}_{2}, \mathrm{GDP}, \mathrm{HD}, \mathrm{IQ}, \\
\mathrm{INV}, \mathrm{FD}, \mathrm{ENC} \text {, and TO }\end{array}$ & $\begin{array}{l}\text { Formal and informal entre- } \\
\text { preneurship contributes } \\
\text { to reducing the quality of } \\
\text { environment. However, } \\
\text { informal entrepreneurship } \\
\text { causes more environmental } \\
\text { degradation compared to } \\
\text { formal entrepreneurship }\end{array}$ \\
\hline Iorember et al (2019) & 1990Q1-2014Q4 & Nigeria and South Africa & RENC, TO, GDP, $\mathrm{CO}_{2}$ & $\begin{array}{l}\text { TO has significant and positive } \\
\text { effect on } \mathrm{CO}_{2} \text { emission }\end{array}$ \\
\hline Saidi and Hammani (2016) & 1990-2012 & $\begin{array}{l}\text { Latin America and the Carib- } \\
\text { bean }\end{array}$ & $\begin{array}{l}\mathrm{GDP}, \mathrm{ENC}, \mathrm{CO}_{2}, \mathrm{FDI}, \mathrm{L} \text {, } \\
\text { and } \mathrm{K}\end{array}$ & $\begin{array}{l}\mathrm{CO}_{2} \text { emission has a negative } \\
\text { impact on GDP }\end{array}$ \\
\hline Cowan et al (2014) & $1990-2010$ & BRICS & ELEC, GDP, $\mathrm{CO}_{2}$ & ELEC improves $\mathrm{CO}_{2}$ \\
\hline Al-Mulali and Sab (2012) & $1980-2008$ & Sub-Sahara African countries & $\mathrm{ENC}, \mathrm{GDP}, \mathrm{FD}, \mathrm{CO}_{2}$ & $\begin{array}{l}\text { ENC improves economic } \\
\text { performance and FD } \\
\text { ENC increases } \mathrm{CO}_{2} \text { emission }\end{array}$ \\
\hline
\end{tabular}

ENT, entrepreneurship; $\mathrm{CO}_{2}$, carbon emission; RGDP, real gross domestic product; HD, human development; TO, trade openness; ENC, energy consumption; FD, financial development; INV, innovation; RENC, renewable energy consumption; NREC, nonrenewable energy consumption; FDI, foreign direct investment; URB, urbanization; L, labor force; K, capital stock; TI, technological innovation; EXR, exchange rate; ELEC, electricity; EP, ecological footprint; POP, population; EU, energy use; GLB, globalization; MKT CAP, market capitalization; IQ, institutional quality; APS, adult population survey; NES, national expert survey; EI, energy innovation; NR, natural resources; SMT, stock market turnover

relationship is examined with the help of the variables, financial development (FD), openness (TO), energy use (EU), and economic performance (Y). $\mathrm{CO}_{2}$ emission, as a dependent variable in our empirical estimation, is used to indicate the environmental quality in our estimations and measured in kilogram per 2010 US $\$$ of gross domestic product (GDP). Financial development was measured by domestic credit to private sector by banks in Turkey measured in the percentage of GDP. Openness of country is expressed as the summation of invisible and visible trade as the percentage of GDP. The indicator of energy use is assessed in kilogram of oil equivalent per capita, while economic performance is measured in per capita GDP (constant 2010 US\$). The total number of new registered businesses is used to assess entrepreneurship activity in Turkey. The model for our study has been constructed with the light of recent studies by Philip et al. (2021), Karasoy (2019) and Youssef et al. (2018).

Depending on the availability of the data, yearly data are used for the period 1985-2016 for estimation output. The World Bank's World Development Indicator (WDI) Database is used to obtain the required data for sampled variables except for the entrepreneurship variable. The data for entrepreneurship activities in Turkey have been compiled from the Union of Chambers and Commodity Exchanges of Turkey (TOBB) official website.

\section{Preliminary estimates}

To get robust results, the logarithmic form of the variables is used, and their normality assumptions are tested according to the Jarque-Bera test statistics. Normality assumption is valid for all variables. On the other hand, the linkage among all investigated variables is introduced in the below equation:

$\mathrm{CO}_{2 t}=\beta_{0}+\beta_{1} E N T+\beta_{2} Y+\beta_{3} E U+\beta_{4} F D+\beta_{5} T O+\varepsilon_{t}$

where $\mathrm{CO}_{2 t}$ indicates the environmental quality in period $t, \mathrm{ENT}_{t}$ represents the total number of new registered businesses in period $\mathrm{t}$; $Y_{t}$ stands for the per capita GDP in period $t ; \mathrm{EU}_{t}$ shows the non-renewable energy use in period $t ; \mathrm{FD}_{t}$ signifies the financial development in period $t$, and $\mathrm{TO}_{t}$ signifies the trade openness in period $t$, while $\beta_{0}$ is a constant term; $\beta_{1}, \beta_{2}, \beta_{3}, \beta_{4}$, and $\beta_{5}$ are the respective coefficients of independent variables. The $\varepsilon_{t}$ stands for the residuals of the empirical estimation.

\section{Method}

Moreover, we believe that entrepreneurship and environmental quality are very sensitive to the instabilities in the economic and political decisions. Thus, changes in economic and political policies may cause positive and negative shocks for these variables in short run and long run. Like entrepreneurship and environmental degradation, openness and financial development also are affected by the inconsistent policies. However, traditional time series models stated in the previous section are not able to capture the asymmetric and nonlinear effect among variables. In this model, besides, 
we assume the nonlinear relationship among variables, the systematic adjustments are also expected to be observed. For this purpose, the nonlinear autoregressive distributed lag model (NARDL) is engaged to investigate the reaction of environmental quality for the different shocks of the explanatory variables. The NARDL is a strengthened version of the ARDL model (Peseran et al. 2001).

\section{The NARDL method}

The model of nonlinear ARDL proposed by Shin et al. (2014) helps us to capture the relationship of differently integrated variables and assures robust results with low observation levels. Additionally, since the model eliminates the endogeneity problems and corrects the residual serial correlations, the negative and positive shocks for investigated variables can be captured with the following equation:

$$
\begin{aligned}
\mathrm{Co}_{2}= & \beta_{0}+\beta_{1} E N T^{+}+\beta_{2} E N T^{-}+\beta_{3} Y^{+}+\beta_{4} Y^{-} \\
& +\beta_{5} E U^{+}+\beta_{6} E U^{-}+\beta_{7} F D^{+}+\beta_{8} F D^{-} \\
& +\beta_{9} T O^{+}+\beta_{10} T O^{-}+\varepsilon_{t}
\end{aligned}
$$

where + and - signs on the independent variables denote the positive and negative components of the explanatory variables. Moreover, the partial sum process can be used to synthesize the components of the shocks in the model. The process is presented below:

$$
\begin{aligned}
& \mathrm{ENT}_{t}^{+}=\sum_{i=1}^{t} \Delta E N T_{i}^{+}=\sum_{i}^{t} \\
& E N T_{t}^{-}=\sum_{i=1}^{t} \Delta E N T_{i}^{-}=\sum_{i}^{t} \\
& Y_{t}^{+}=\sum_{i=1}^{t} \Delta Y_{i}^{+}=\sum_{i}^{t} \\
& Y_{t}^{-}=\sum_{i=1}^{t} \Delta Y_{i}^{-}=\sum_{i}^{t} \\
& E U_{t}^{+}=\sum_{i=1}^{t} \Delta E U_{i}^{+}=\sum_{i}^{t} \\
& E U_{t}^{-}=\sum_{i=1}^{t} \Delta E U_{i}^{-}=\sum_{i}^{t} \\
& F D_{t}^{+}=\sum_{i=1}^{t} \Delta F D_{i}^{+}=\sum_{i}^{t} \\
& F D_{t}^{-}=\sum_{i=1}^{t} \Delta F D_{i}^{-}=\sum_{i}^{t} \\
& T \mathrm{O}_{t}^{+}=\sum_{i=1}^{t} \Delta T \mathrm{O}_{i}^{+}=\sum_{i}^{t} \\
& T O_{t}^{-}=\sum_{i=1}^{t} \Delta T O_{i}^{-}=\sum_{i}^{t}
\end{aligned}
$$

The term dynamics may be encompassed as follows:

$$
\begin{gathered}
\Delta C O_{2 t}=\alpha_{0}+\phi_{1} C o_{2 t-1}+\beta_{1}^{+} E N T_{t-1}^{+}+\beta_{2}^{-} E N T_{t-1}^{-}+\gamma_{3}^{+} Y_{t-1}^{+}+\gamma_{4}^{-} Y_{t-1}^{-}+\lambda_{4}^{+} E U_{t-1}^{+}+\lambda_{4}^{-} E U_{t-1}^{-}+\varphi_{5}^{+} F D_{t-1}^{+}+\varphi_{6}^{-} F D_{t-1}^{-}+ \\
\psi_{7}^{+} T O_{t-1}^{+}+\psi_{8}^{-} T O_{t-1}^{-}+\sum_{i=1}^{p-1} \delta C O_{2 t-i}+\sum_{i=0}^{q-1} \begin{array}{l}
\left(\vartheta_{1}^{+} \Delta E N T_{t-1}^{+}+\vartheta_{2}^{-} \Delta E N T_{t-1}^{-}+\right. \\
\vartheta_{3}^{+} \Delta Y_{t-1}^{+}+\vartheta_{4}^{-} \Delta Y_{t-1}^{-}+\vartheta_{4}^{+} \Delta E U_{t-1}^{+}+\vartheta_{5}^{-} \Delta E U_{t-1}^{-}+ \\
\vartheta_{6}^{+} \Delta F D_{t-1}^{+}+\vartheta_{7}^{-} \Delta F D_{t-1}^{-}+\vartheta_{8}^{+} \Delta T O_{t-1}^{+}+\vartheta_{9}^{-} \Delta T O_{t-1}^{-}
\end{array}
\end{gathered}
$$

With the addition of the error correction term (ECT), Eq. 4 is converted into the error correction model:

$$
\begin{aligned}
& \Delta C O_{2 t}=\alpha_{0}+\phi_{1} C O_{2 t-1}+\beta_{1}^{+} E N T_{t-1}^{+}+\beta_{2}^{-} E N T_{t-1}^{-}+\gamma_{3}^{+} Y_{t-1}^{+}+\gamma_{4}^{-} Y_{t-1}^{-}+\lambda_{4}^{+} E U_{t-1}^{+}+\lambda_{4}^{-} E U_{t-1}^{-}+\varphi_{5}^{+} F D_{t-1}^{+}+\varphi_{6}^{-} F D_{t-1}^{-}+ \\
& \psi_{7}^{+} T O_{t-1}^{+}+\psi_{8}^{-} T O_{t-1}^{-}+\sum_{i=1}^{p-1} \delta C O_{2 t-i}+\sum_{i=0}^{q-1} \begin{array}{l}
\left(\vartheta_{1}^{+} \Delta E N T_{t-1}^{+}+\vartheta_{2}^{-} \Delta E N T_{t-1}^{-}+\right. \\
\left.\vartheta_{3}^{+} \Delta Y_{t-1}^{+}+\vartheta_{4}^{-} \Delta Y_{t-1}^{-}+\vartheta_{4}^{+} \Delta E U_{t-1}^{+}+\vartheta_{5}^{-} \Delta E U_{t-1}^{-}+\right)+\eta E C T_{t-1}+\varepsilon_{t} \\
\vartheta_{t-1}^{+} \Delta F D_{7}^{+} \Delta F D_{t-1}^{-}+\vartheta_{8}^{+} \Delta T O_{t-1}^{+}+\vartheta_{9}^{-} \Delta T O_{t-1}^{-}
\end{array}
\end{aligned}
$$


Table 2 Stationarity test results

\begin{tabular}{|c|c|c|c|c|c|c|c|c|c|c|c|}
\hline \multirow[t]{2}{*}{ Variables } & \multicolumn{2}{|l|}{$A D F$} & \multicolumn{2}{|l|}{$P P$} & \multicolumn{2}{|l|}{$D F-G L S$} & \multicolumn{2}{|l|}{ KPSS } & \multicolumn{3}{|c|}{ Zivot-Andrews Test } \\
\hline & Level & $\Delta$ & Level & $\Delta$ & Level & $\Delta$ & Level & $\Delta$ & Level & $\Delta$ & Break year \\
\hline $\mathrm{CO}_{2}$ & -0.414 & $-6.42 * * *$ & -0.044 & $-7.758 * * *$ & -0.526 & $-6.135 * * *$ & 0.739 & $0.160 * * *$ & -4.52 & $-6.824 * * *$ & 2003 \\
\hline ENT & -1.789 & $-5.179 * * *$ & -1.879 & $-5.171 * * *$ & -1.316 & $-5.271 * * *$ & 0.510 & $0.059 * * *$ & -4.248 & $-5.818 * * *$ & 1999 \\
\hline $\mathrm{Y}$ & 0.028 & $-5.822 * * *$ & 0.285 & $-5.995 * * *$ & 1.019 & $-5.839 * * *$ & 0.743 & $0.121 * * *$ & -3.283 & $-5.638 * * *$ & 2011 \\
\hline EU & -0.223 & $-5.934 * * *$ & 0.277 & $-7.285^{* * *}$ & 0.683 & $-5.989 * * *$ & 0.737 & $0.196 * * *$ & -3.934 & $-5.733 * * *$ & 2003 \\
\hline FD & 2.173 & $-3.643 * * *$ & 1.912 & $-3.607 * * *$ & 0.661 & $-3.685^{* * *}$ & 0.539 & $0.517 * * *$ & -2.268 & $-6.198 * * *$ & 1998 \\
\hline TO & -1.729 & $-5.461 * * *$ & -1.476 & $-7.096 * * *$ & -1.508 & $-4.524 * * *$ & 0.639 & $0.289 * * *$ & -5.334 & $-5.579 * * *$ & 1994 \\
\hline
\end{tabular}

$* * *$ States the significance level at $1 \%$

Table 3 Bound test results

\begin{tabular}{|c|c|c|c|c|c|c|c|}
\hline \multirow[t]{2}{*}{$\mathrm{K}$} & \multirow{2}{*}{$\begin{array}{l}\text { Calculated } \\
\text { F-statistic }\end{array}$} & \multicolumn{2}{|l|}{$1 \%$} & \multicolumn{2}{|l|}{$5 \%$} & \multicolumn{2}{|l|}{$10 \%$} \\
\hline & & $\overline{\mathrm{LB}}$ & UB & $\overline{\mathrm{LB}}$ & $\overline{\mathrm{UB}}$ & $\overline{\mathrm{LB}}$ & UB \\
\hline 6 & 6.47 & 3.15 & 4.43 & 2.45 & 3.61 & 2.12 & 3.23 \\
\hline
\end{tabular}

Note: UB: upper critical bound LB: lower critical bound

The short-run dynamics are indicated with a different operator which is denoted $\Delta$ in the above equation. Moreover, level variables are used to capture the long-run dynamics. Here, in this equation, the lag orders are signified with $\mathrm{q}$ and $p$. The information of the effects of positive and negative shocks in the explanatory variables on environmental quality is captured with the values of $\sum_{i=0}^{q-1}\left(\vartheta_{i}^{+}\right)$and $\sum_{i=0}^{q-1}\left(\vartheta_{t}^{-}\right)$. Furthermore, the presence or lack of the cointegration relationship among variables is tested by employing the Wald test. The testing hypothesis of the Wald test is given in the following equation:

$H_{0}: \beta_{i}^{\prime} s=\gamma_{i}^{\prime} s=0$

$H_{0}: \beta_{i}^{\prime} s=\gamma_{i}^{\prime} s \neq 0$

Following this step, the existence of the long-run asymmetries will be examined among the investigated variables by using the hypothesis of $H_{0}: \beta_{1}^{+}=\beta_{2}^{-}$or otherwise and $H_{0}: \gamma_{3}^{+}=\gamma_{4}^{-}$or otherwise. At the last step, the long-run estimation output of NARDL is confirmed with the fully modified ordinary least squared model (FMOLS) and the goodness of fit for the NARDL model. The result obtained is further checked through the cumulative sum of recursive residuals (CUSUM) and the cumulative sum of recursive residuals squares (CUSUMSQ) stability tests.

\section{Results and discussion}

In this study, the purpose is to assess the short-run and long-run asymmetric association between entrepreneurship and environmental quality for the second most entrepreneurial country, Turkey. The period is investigated between 1985 and 2016 due to data availability. To this extent, as the first step, the level of integration for the investigated variables is tested and the level of integration for each variable is determined. To do this, we employed several unit root tests depending on their benefits and drawbacks. All of these tests ${ }^{1}$ are presented in Table 1 and display that sampled variables are stationary at their first-differenced form. Furthermore, Zivot and Andrews (1992) test is utilized to detect the structural break of the investigated variables. This test suggests that 1994, 1998, 1999, and 2011 are the break years for openness, financial development, entrepreneurship, and economic growth, respectively.

However, the break year for both environmental quality and non-renewable energy use has been calculated for 2003. The reason is, in 1994 and 2001, Turkey has experienced an economic and political crisis. Large governmental expenditures, high-interest rates, and failure to implement structural reforms have delayed solving fundamental problems. Therefore, the economy spent a long time recovering itself. On the other hand, the energy sector was mostly owned by the public until 2001. To meet the rising energy consumption and to improve the functioning of the energy sector, many incentives have been provided to the private sector to encourage them to invest in energy projects. However, the desired results could not be obtained until 2001. After 2001, with the harmful effect of the global economic

\footnotetext{
${ }^{1}$ Dickey-Fuller generalized least squares (DF-GLS) test (Elliot et al.,1996)), KPSS test ( Kwiatkowski et al.1992)test Augmented Dickey-Fuller(ADF) test (Dickey and Fuller 1979) and Phillips and Perron (1990).
} 
Table 4 Estimation output

\begin{tabular}{|c|c|c|}
\hline \multicolumn{3}{|l|}{ Short Run } \\
\hline Variables & Coefficient & P-values \\
\hline $\mathrm{D}\left(\mathrm{LENT}^{+}\right)$ & 0.109 & $0.001 * * *$ \\
\hline $\mathrm{D}\left(\mathrm{LENT}^{-}\right)$ & 0.044 & $0.016^{* *}$ \\
\hline $\mathrm{D}\left(\mathrm{LEU}^{+}\right)$ & 1.479 & $0.000 * * *$ \\
\hline D(LEU-) & 0.701 & $0.010 * * *$ \\
\hline $\mathrm{D}\left(\mathrm{LFD}^{+}\right)$ & 0.088 & $0.013^{* *}$ \\
\hline $\mathrm{D}\left(\mathrm{LFD}^{-}\right)$ & 0.198 & $0.017 * *$ \\
\hline $\mathrm{D}\left(\mathrm{LTO}^{+}\right)$ & 0.129 & $0.091 *$ \\
\hline $\mathrm{D}\left(\mathrm{LTO}^{-}\right)$ & -0.393 & $0.002 * * *$ \\
\hline $\mathrm{D}\left(\mathrm{LY}^{+}\right)$ & 0.943 & $0.000 * * *$ \\
\hline $\mathrm{D}\left(\mathrm{LY}^{-}\right)$ & 0.237 & $0.030 * *$ \\
\hline ECT(-1) & -0.532 & $0.000 * * *$ \\
\hline \multicolumn{3}{|l|}{ Long Run } \\
\hline Variable & Coefficient & Prob \\
\hline $\mathrm{LENT}^{+}$ & 0.006 & $0.059 *$ \\
\hline LENT $^{-}$ & 0.028 & $0.017 * *$ \\
\hline $\mathrm{LEU}^{+}$ & 1.383 & $0.000 * * *$ \\
\hline $\mathrm{LEU}^{-}$ & 1.001 & $0.001 * * *$ \\
\hline $\mathrm{LFD}^{+}$ & 0.037 & $0.014 * *$ \\
\hline $\mathrm{LFD}^{-}$ & 0.012 & $0.084 *$ \\
\hline $\mathrm{LTO}^{+}$ & 0.044 & $0.052 *$ \\
\hline $\mathrm{LTO}^{-}$ & -0.061 & $0.046^{* *}$ \\
\hline $\mathrm{LY}^{+}$ & 0.187 & $0.045^{* *}$ \\
\hline $\mathrm{LY}^{-}$ & 0.082 & $0.079 *$ \\
\hline $\mathrm{C}$ & 0.766 & $0.000 * * *$ \\
\hline
\end{tabular}

*****, and ${ }^{*}$ denote the significance levels at $1 \%, 5 \%$, and $10 \%$, respectively

and financial crisis, Turkish government decided to privatize the lignite mines, power plants, and distribution activities in the electricity sector. For this reason, it affects the efficiency in the production of energy, as well as an investment in the renewable energy sector will contribute to the environmental quality and can cause sustainability. The structural breaks with unit root amplify the applicability of the nonlinear ARDL model to our research.

\section{The NARDL result and discussion}

On the other hand, as the first step, the bounds test is employed as a pre-condition of the NARDL model to extract the long-run association among investigated variables. Table 1 represents the findings of the bounds test and shows the presence of cointegration among the variables. Since the upper critical bound (4.43) at $1 \%$ of significance level is smaller than the calculated F-statistic (6.47), the Ho is rejected, which indicated the cointegration amidst variables exists. Also, the test result indicates that any changes in the level of entrepreneurship and other explanatory variables have significant effects on the environmental quality, and this proves our theoretical assumptions (Tables 2 and 3).

Moreover, to scrutinize the asymmetric effects of investigated variables on environmental quality, the NARDL method is employed and elaborated in Table 4.

Although the magnitudes of the shocks are different in both terms, the coefficients of all investigated variables are statistically significant at different level of significance. Therefore, it can easily be understood that the investigated variables have asymmetric relations with environmental quality. The coefficient of ECT is negative and statistically significant at $1 \%$ level. This confirms the presence of cointegration. The coefficient of ECT is 0.532 , which concludes that $53.2 \%$ of the disequilibrium in the environmental quality is rectified in the short run given the independent variables. Given the significant coefficients of entrepreneurship in both terms, a $1 \%$ increment in entrepreneurship (due to a positive shock) deteriorates the environmental quality by $0.109 \%$ at $1 \%$ significance level, while $1 \%$ decrease in entrepreneurship 
(due to a negative shock) increases the environmental quality by $0.044 \%$ at $5 \%$ significance level in the short run. Likewise, if there is an amendment in entrepreneurship, say $1 \%$, this will deteriorate the environment by $0.006 \%$ and cause a decline in environmental quality at $10 \%$ significance level, while a $1 \%$ decrease in entrepreneurship contributes to the environmental quality by $0.028 \%$ at $5 \%$ significance level in the long run. These results indicate that entrepreneurial activities in emerging economies deteriorate environmental quality. These results are parallel with Dhahri and Omri (2018) Youssef et al (2018) and He et al. (2020). To this end, Youssef et al. (2018) suggested that innovation and institutional quality should be supported and developed by policymakers to make sustainable formal entrepreneurship to decrease the level of environmental degradation.

Moreover, the coefficients of FD are statistically significant in both terms. If there is $1 \%$ increase in FD, then on average, environmental degradation will increase by $0.088 \%$, whereas a one-percent fall in FD will contribute to the environment by $0.198 \%$, in the short run. Similarly, it can easily be understood the asymmetric relation between FD and environmental degradation because positive and negative shocks significantly contribute to environmental degradation in the long run, but do not have the same contribution level in both terms. These findings are parallel to the Karasol (2019) study and Ozturk and Acaravci (2013) research which are done for Turkish economy.

A positive and negative shock of inadequate utilization of energy usage deteriorates environmental quality in both terms. The coefficients of the EU show that the rise in energy use in Turkey by one percent will cause a rise in environmental degradation level and declines the environmental quality by $1.479 \%$, while the coefficient of EU is significant at $1 \%$ and indicates that $1 \%$ decrease in energy use will increase the quality of environmental by $0.701 \%$. These coefficients, in the long run, are 1.383 and 1.001 and show the same effect on environmental quality in Turkey. These results are parallel to Sharma et al (2020) and Acharya (2003) and demonstrate that an increase in the accessibility to credits in the market increases the consumption of carbon-intensive products (Zhang 2011). Also, accessibility to credits attracts and increases foreign and domestic investments which raises the energy demand in the country. Consequently, this will lead to increase $\mathrm{CO}_{2}$ emissions and cause higher environmental degradation.

However, concerning the coefficients of economic growth, a one percent rise in economic performance (due to a positive shock in the economy) will lead to deterioration of the environment by $0.943 \%$ in the short run, on average. A $1 \%$ decline in the level of economic performance (arising from a negative shock in the economy) will also cause a decline in environmental degradation by $0.237 \%$, on average. Moreover, a one percent increase in economic
Table 5 FMOLS estimation output

\begin{tabular}{lrr}
\hline Variable & Coefficient & Prob \\
\hline ENT & 0.017 & 0.003 \\
EU & 1.116 & 0.000 \\
FD & 0.006 & 0.006 \\
TO & -0.142 & 0.012 \\
Y & 5.327 & 0.001 \\
$\mathrm{Y}^{2}$ & -0.293 & 0.014 \\
C & -30.555 & 0.010 \\
\hline
\end{tabular}

Coefficients are all statistically significant at $1 \%$ significance level

performance will cause $0.187 \%$ increase in environmental degradation in the long run, on average, while a $1 \%$ decrease in the economic performance will contribute to the environmental quality by $0.082 \%$, in the long run, on average. These significant positive and negative shock coefficients in both terms prove the asymmetric relation between these two variables. These results prove that a raise in economic performance will increase productivity and induce output expansion and more energy demand which raises the level of environmental degradation. The findings synchronized with those of Philip et al. (2021) and Ahmed et al (2021) on the Turkish economy.

Furthermore, interestingly, a positive shock in openness will raise environmental degradation by $0.129 \%$, while a negative shock of openness will also raise environmental degradation by $0.393 \%$, on average. Also, positive shocks in TO significantly contribute to $\mathrm{CO} 2$ emission and deteriorate the environmental sustainability by $0.044 \%$, on average while a $1 \%$ increase in negative shocks of $\mathrm{TO}$ will increase environmental pollution by $0.061 \%$, on average. Results are consistent with Audi and Ali (2018) and Holladay (2016). This may be because Turkey is an import dependent country and negative shocks on TO can cause people to be sensitive to imported products and continue to consume more traditional and carbon emitter products.

Here, it is very important to conclude that since one unit change in independent variables does not cause the same changes in the dependent variable, the results prove the presence of a nonlinear and asymmetric association among investigated variables.

\section{Diagnostic and robustness estimates}

Following this, we added GDP squares into the model and check the validity of EKC hypothesis with FMOLS model. The FMOLS is also employed to confirm the consistency and the robustness of the long-run effects of the investigated variables on the environmental quality in Turkey. Table 4 of 
Table 6 Diagnostic test results

\begin{tabular}{lll}
\hline Tests & Statistics & Probability \\
\hline BG-LM test & 1.561 & 0.275 \\
BPG & 6.410 & 0.004 \\
RESET & 1.471 & 0.1796 \\
ARCH & 1.138 & 0.2953 \\
Jarque-Bera test & 0.444 & 0.800 \\
\hline
\end{tabular}

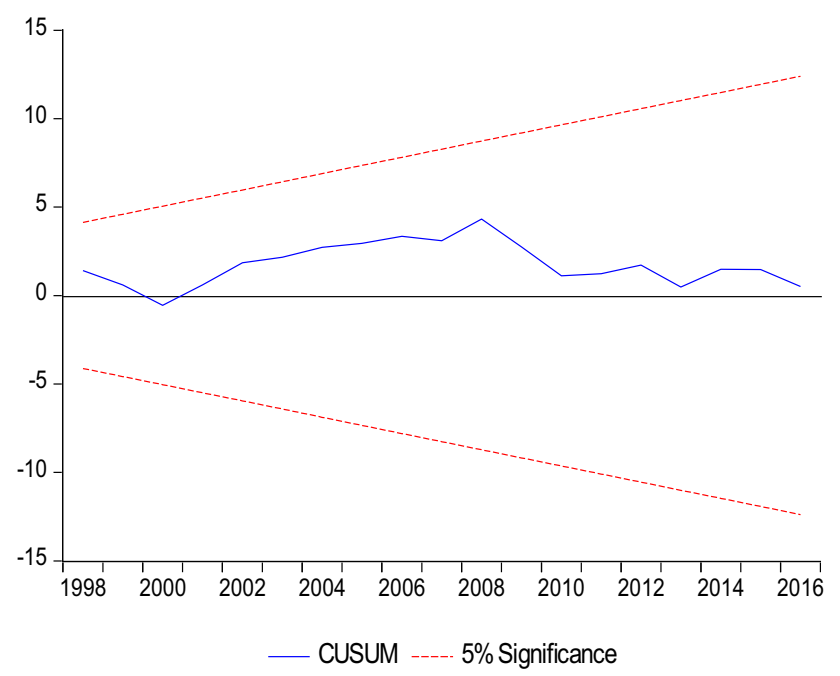

Fig. 1 CUSUM test result

the NARDL model proves that it is statistically significant and the long-run effect of the independent variables on environmental degradation. At a first glance, according to the estimation output of FMOLS model, the inverted U-shaped of the EKC hypothesis is confirmed for Turkey since $\mathrm{Y}$ and $\mathrm{Y}^{2}$ have positive and negative statistically significant coefficients (see Table 5). Accordingly, a rise in economic performance first raises environmental pollution and decreases environmental quality. After some level of performance, the level of environmental pollution leads to decline and this will lead to a rise in environmental quality. Moreover, the increase in entrepreneurship by $1 \%$ will deteriorate with $0.017 \%$ of extra carbon dioxide emission to the air. A one percent rise in energy demand in Turkey will rise environmental deterioration by $1.116 \%$, and an increase in financial development by $1 \%$ will have smaller impact on environmental degradation and increase it by $0.006 \%$. However, the overall effect of TO shows that the $1 \%$ increase in import and export of the economy will decrease in environmental degradation and cause an increase in environmental quality by $0.142 \%$. Additionally, the magnitude of economic performance on environmental quality is significant. Thus, among all variables, an increase in GDP will lead to having the most

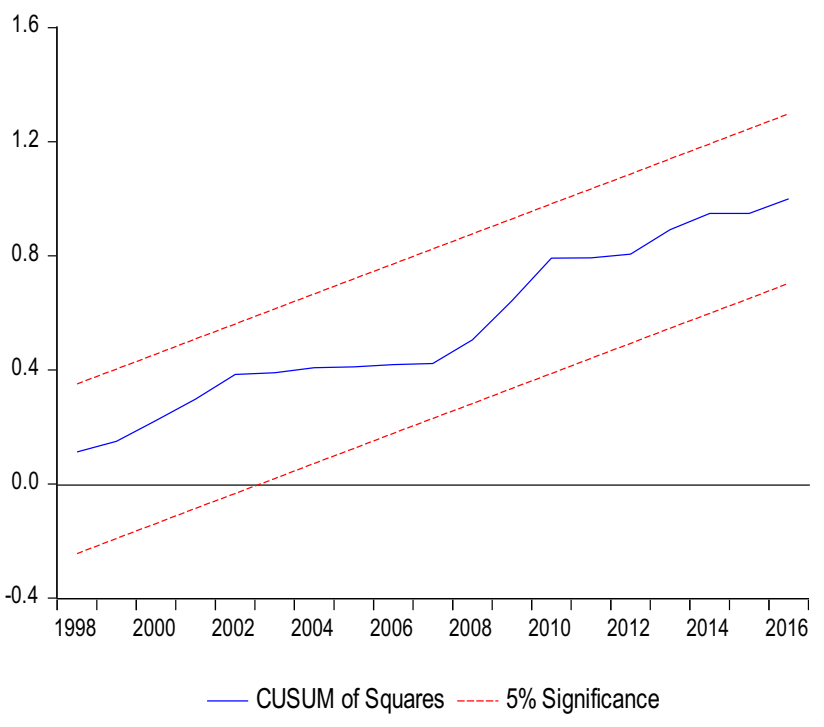

Fig. 2 CUSUMSQ test result

powerful effect on environmental degradation. An increase in the economic performance of Turkey by one percent will raise $\mathrm{CO}_{2}$ emission by $5.327 \%$. Nevertheless, then, it will raise the environmental quality by $0.293 \%$.

\section{Robustness estimates}

To test the reliability of the coefficients, the diagnostic tests are employed and presented in Table 6. Breusch-PaganGodfrey (BPG) and ARCH test are employed for heteroscedasticity test, and Breusch-Godfrey LM (BG-LM) test and Jarque-Bera test are employed for testing autocorrelation and normality. Also, for model specification, the Ramsey RESET test is utilized. All findings reveal that our model is free from these statistical issues.

Moreover, the stability of the NARDL model is tested at the last step. To this end, CUSUM and CUSUMSQ stability tests are employed and, respectively, presented in Figs. 1 and 2 . The findings of these tests prove the stability of the developed model since the plots of the tests are located within the $5 \%$ significance critical bounds.

\section{Conclusion}

The main purpose of this research was to verify the short-run and long-run asymmetric impacts of entrepreneurship on environmental quality incorporating with economic performance, openness, energy and financial development. For this purpose, data for Turkey were gathered from World Bank WDI and TOBB in annual basis for the period 1985-2016. Providing extended theoretical relationship between 
entrepreneurship and environmental quality, an empirical NARDL model has been developed to achieve our purpose and NARDL bounds test has been employed to investigate cointegration among sampled variables. To test the strength and consistency of the estimation results, the long-run coefficients are estimated with another model, i.e., FMOLS, and consistency has been approved.

The results of this study, in general, provide that an increase or decrease in the degree of entrepreneurship and other investigated variables has statistically significant association with environmental quality, and this proves our asymmetric short-run and long-run deterioration effects of the sampled variables on environment assumptions. In the previous section, the empirical findings are well discussed with their reasons in detail. As a summary, estimation results showed that the overall effects of all investigated variables increase environmental degradation except for trade openness. These results showed that entrepreneurial activities deteriorate the environment in Turkey, since economic growth is prioritized to environmental quality/sustainability in emerging economies.

Furthermore, the validity of EKC hypothesis was tested with FMOLS model. This model was also employed to confirm the significance and the long-run outcome of the investigated variables on the environmental degradation and to test their robustness in Turkey. Additionally, the inverted U-shaped EKC hypothesis was also confirmed in this model. The EKC hypothesis was confirmed for Turkish economy since the coefficient of economic performance is positive and the coefficient of the square of it is negative and statistically significant. Accordingly, an increase in the economic performance first emits large emissions to the environment and deteriorates environmental quality, and after a certain level of GDP, the growth in economic performance will cause a decline in the environmental pollution and increases environmental quality. The reason is that people tend to consume more capital intensive environmentally friendly products since they prioritize the environment with an increase in income level.

The literature gap is filled by testing the asymmetric impact of entrepreneurship on environmental quality in Turkey. The topic has limited recognition in the literature. Most of the studies are based on entrepreneurship and how it contributes to economic growth. This study provides vital suggestions for researchers and entrepreneurs when having the decision to set up a business to have a better understanding of how economic regulations can simplify the growth of entrepreneurship, and also, motivate the creation of new businesses by introducing an incentive to increase the number of entrepreneurs and to register their business when possible. Moreover, opportunities should be created for technological innovation and green building to minimize environmental degradation. Future studies may use different indicators for environmental quality to develop this relationship, such as environmental performance index, and focus on how to minimize the negative impact on the environment. Moreover, panel data can be used to make the comparison about the nature of asymmetric relationship among all emerging economies that have the same economic structure.

Acknowledgements Authors appreciate the work of the Editor(s) and anonymous referees.

Funding Open access funding provided by University of Vaasa (UVA).

\section{Compliance with Ethical Standards}

Conflicts of interest The authors declare that they have no conflict of interests.

Open Access This article is licensed under a Creative Commons Attribution 4.0 International License, which permits use, sharing, adaptation, distribution and reproduction in any medium or format, as long as you give appropriate credit to the original author(s) and the source, provide a link to the Creative Commons licence, and indicate if changes were made. The images or other third party material in this article are included in the article's Creative Commons licence, unless indicated otherwise in a credit line to the material. If material is not included in the article's Creative Commons licence and your intended use is not permitted by statutory regulation or exceeds the permitted use, you will need to obtain permission directly from the copyright holder. To view a copy of this licence, visit http://creativecommons.org/licenses/by/4.0/.

\section{References}

Abbasi F, Riaz K (2016) $\mathrm{CO}_{2}$ emissions and financial development in an emerging economy: an augmented VAR approach. Energy Policy 90:102-114

Acharya M (2003) Development of the financial system and its impact on poverty alleviation in Nepal. Econ Rev 15(1):134-164

AhAtil, A., Bouheni, F. B., Lahiani, A., \& Shahbaz, M. (2019). Factors influencing $\mathrm{CO}_{2}$ emission in China: a nonlinear autoregressive distributed lags investigation.

Ahmed Z, Zhang B, Cary M (2021) Linking economic globalization, economic growth, financial development, and ecological footprint: Evidence from symmetric and asymmetric ARDL. Ecol Indic 121:107060

Al-Mulali U, Sab CNBC (2012) The impact of energy consumption and $\mathrm{CO}_{2}$ emission on the economic growth and financial development in the Sub Saharan African countries. Energy 39(1):180-186

Alola AA, Akadiri SS, Usman O (2021) Domestic material consumption and greenhouse gas emissions in the EU-28 countries: Implications for environmental sustainability targets. Sustain Dev 29(2):388-397

Alola AA, Bekun FV, Sarkodie SA (2019) Dynamic impact of trade policy, economic growth, fertility rate, renewable and non-renewable energy consumption on ecological footprint in Europe. Sci Total Environ 685:702-709

Audi, M., \& Ali, A. (2018). Determinants of environmental degradation under the perspective of globalization: a panel analysis of selected MENA nations. https://mpra.ub.uni-muenchen.de/ 85776/ 
Balsalobre-Lorente D, Shahbaz M, Roubaud D, Farhani S (2018) How economic growth, renewable electricity and natural resources contribute to $\mathrm{CO}_{2}$ emissions? Energy Policy 113:356-367

Bekun FV, Alola AA, Sarkodie SA (2019) Toward a sustainable environment: Nexus between $\mathrm{CO}_{2}$ emissions, resource rent, renewable and nonrenewable energy in 16-EU countries. Sci Total Environ 657:1023-1029

Cai Y, Sam CY, Chang T (2018) Nexus between clean energy consumption, economic growth and $\mathrm{CO}_{2}$ emissions. J Clean Prod 182:1001-1011

Cohen B, Winn MI (2007) Market imperfections, opportunity and sustainable entrepreneurship. J Bus Ventur 22(1):29-49

Cowan WN, Chang T, Inglesi-Lotz R, Gupta R (2014) The nexus of electricity consumption, economic growth and $\mathrm{CO}_{2}$ emissions in the BRICS countries. Energy Policy 66:359-368

Dhahri S, Omri A (2018) Entrepreneurship contribution to the three pillars of sustainable development: What does the evidence really say? World Dev 106:64-77

Dickey DA, Fuller WA (1979) Distribution of the estimators for autoregressive time series with a unit root. J Am Stat Assoc 74(366a):427-431

Gerçeker M, Özel B, Ay A (2014) Effects of entrepreneurship on economic growth in Turkey: an empirical analysis. In: Proceedings of international academic conferences (No. 0702291). International Institute of Social and Economic Sciences.

He J, Nazari M, Zhang Y, Cai N (2020) Opportunity-based entrepreneurship and environmental quality of sustainable development: a resource and institutional perspective. J Cleaner Prod 256:120390

Holladay JS (2016) Exporters and the environment. Can J Econ 49(1):147-172

Ibrahiem DM (2020) Do technological innovations and financial development improve environmental quality in Egypt? Environ Sci Pollut Res 27(10):10869-10881

Iorember, P. T., Usman, O., \& Jelilov, G. (2019). Asymmetric effects of renewable energy consumption, trade openness and economic growth on environmental quality in Nigeria and South Africa.

Karasoy A (2019) Drivers of carbon emissions in Turkey: considering asymmetric impacts. Environ Sci Pollut Res 26(9):9219-9231

Kwiatkowski D, Phillips PCB, Schmidt P, Shin YC (1992) Testing the null hypothesis of stationarity against the alternative of a unitroot: how sure are we that economic time-series have a unit-root. J Econometrics 54:159-178

Lv Z, Li S (2021) How financial development affects $\mathrm{CO}_{2}$ emissions: a spatial econometric analysis. Journal of Environmental Management 277

Mikayilov JI, Galeotti M, Hasanov FJ (2018) The impact of economic growth on $\mathrm{CO}_{2}$ emissions in Azerbaijan. J Clean Prod 197:1558-1572

Nakamura H, Managi S (2020) Entrepreneurship and marginal cost of $\mathrm{CO}_{2}$ emissions in economic development. Econ Anal Policy 67:1-14

Omoke PC, Opuala-Charles S, Nwani C (2020) Symmetric and asymmetric effects of financial development on carbon dioxide emissions in Nigeria: evidence from linear and nonlinear autoregressive distributed lag analyses. Energy Explor Exploit 38(5):2059-2078

Omri A (2018) Entrepreneurship, sectoral outputs and environmental improvement: international evidence. Technol Forecast Soc Chang $128: 46-55$

Omri A, Afi H (2020) How can entrepreneurship and educational capital lead to environmental sustainability? Struct Chang Econ Dyn 54:1-10
Ozturk I, Acaravci A (2013) The long-run and causal analysis of energy, growth, openness and financial development on carbon emissions in Turkey. Energy Economics 36:262-267

Pesaran MH, Shin Y, Smith RJ (2001) Bounds testing approaches to the analysis of level relationships. J Appl Econ 16(3):289-326

Philip LD, Sertoglu K, Saint Akadiri S, Olasehinde-Williams G (2021) Foreign direct investment amidst global economic downturn: is there a time-varying implication for environmental sustainability targets? Environ Sci Pollut Res, 1-10

Perron P (1990) Testing for a unit root in a time series with a changing mean. J Bus Econ Stat 8(2):153-162

Riti JS, Dankumo AM, Gubak HD (2015) Entrepreneurship and environmental sustainability: evidence from Nigeria

Saboori B, Sulaiman J, Mohd S (2012) Economic growth and $\mathrm{CO}_{2}$ emissions in Malaysia: a cointegration analysis of the environmental Kuznets curve. Energy Policy 51:184-191

Saidi K, Hammami S (2016) Economic growth, energy consumption and carbone dioxide emissions: recent evidence from panel data analysis for 58 countries. Qual Quant 50(1):361-383

Saint Akadiri, S., Alola, A. A., Olasehinde-Williams, G., \& Etokakpan, M. U. (2020). The role of electricity consumption, globalization and economic growth in carbon dioxide emissions and its implications for environmental sustainability targets. Science of The Total Environment, 708, 134653.

Schumpeter JA (1947) Theoretical problems of economic growth. J Econ History Suppl, 1-9

Shahbaz M, Tiwari AK, Nasir M (2013) The effects of financial development, economic growth, coal consumption and trade openness on $\mathrm{CO}_{2}$ emissions in South Africa. Energy Policy 61:1452-1459

Sharma R, Sinha A, Kautish P (2020) Does renewable energy consumption reduce ecological footprint? Evidence from eight developing countries of Asia. J Clean Prod https://doi.org/10.1016/j. jclepro.2020.124867

Shepherd DA, Patzelt H (2011) The new field of sustainable entrepreneurship: Studying entrepreneurial action linking "what is to be sustained" with "what is to be developed." Entrep Theory Pract 35(1):137-163

Shin Y, Yu B, Greenwood-Nimmo M (2014) Modelling asymmetric cointegration and dynamic multipliers in a nonlinear ARDL framework. Festschrift in Honor of Peter Schmidt. Springer, New York, pp 281-314

Umar M, Ji X, Kirikkaleli D, Alola AA (2021) The imperativeness of environmental quality in the United States transportation sector amidst biomass-fossil energy consumption and growth. J Clean Prod 285:124863

Urbano D, Aparicio S (2016) Entrepreneurship capital types and economic growth: International evidence. Technol Forecast Soc Chang 102:34-44

York JG, Venkataraman S (2010) The entrepreneur-environment nexus: Uncertainty, innovation, and allocation. J Bus Ventur 25(5):449-463

Youssef AB, Boubaker S, Omri A (2018) Entrepreneurship and sustainability: the need for innovative and institutional solutions. Technol Forecast Soc Chang 129:232-241

Zhang YJ (2011) The impact of financial development on carbon emissions: an empirical analysis in China. Energy Policy 39(4):2197-2203

Zivot E, Andrews DWK (1992) Further evidence on the great crash, the oil-price shock, and the unit-root hypothesis. J Bus Econ Stat 10(3):251-270. https://doi.org/10.1080/07350015.1992.10509904 